
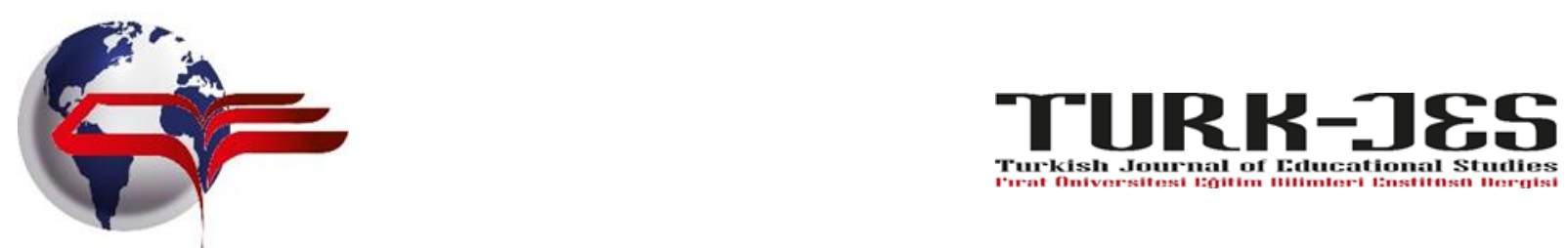

Turkish Journal of Educational Studies, 5 (3) Ekim 2018 Research Article / Araştırma Makalesi

Article Info/Makale Bilgisi

Received/Geliş: Ekim 2018 Accepted/Kabul: Ekim 2018

\title{
Farklı Branşlardaki Öğretmen Adaylarının Değerlendirme Okuryazarlığı ve Değerlendirme Okuryazarlığına İlişkin Öz-Yeterliklerinin İncelenmesi*
}

\section{Investigating the Pre-Service Teachers' Assessment Literacy in different fields and Self-Efficacy in terms of Assessment Literacy}

\author{
Öznur ÇAMBAY** $\quad$ Sefa KAZANÇ***
}

\section{Öz}

$\mathrm{Bu}$ çalışma, öğretmen adaylarının değerlendirme okuryazarlıkları ve değerlendirme okuryazarlığına ilişkin özyeterlikleri tarama modeli kullanılarak araştırılmıştır. Ayrıca, bu araştırmada öğretmen adaylarının değerlendirme okuryazarlıkları ve değerlendirme okuryazarlığına ilişkin öz-yeterlikleri arasındaki ilişkiler de incelenmiştir. Bu çalışmaya, 2015-2016 öğretim yılı Fırat Üniversitesi Fen Bilgisi, Sınıf ve Okul Öncesi Öğretmenliği programı dördüncü sınıfta öğrenim gören 35'er kişilik toplamda 105 öğretmen adayı katılmıştır. Araştırmada veri toplama aracı olarak, anketler ve bireysel yarı-yapılandırılmış mülakatlar kullanılmıştır. Öğretmen adaylarının değerlendirme okuryazarlıklarını ve değerlendirme okuryazarlığına ilişkin öz-yeterlik algılarını belirlemek için çalışma sonucunda elde edilen verilere Çok Değişkenli Varyans Analizi (MANOVA) ve Pearson Korelasyon analizi uygulanmıştır. Yapılan istatistiksel analizler sonucunda, öğretmen adaylarının değerlendirme okuryazarlıkları ve değerlendirme okuryazarlıklarına ilişkin öz-yeterlikleri arasında anlamlı bir farklılığın olduğu tespit edilmiştir. Ayrıca fen bilgisi, sınıf ve okul öncesi öğretmen adaylarının değerlendirme okuryazarlığı ve değerlendirme okuryazarlığına ilişkin öz-yeterlikleri arasında istatistiksel olarak anlamlı bir ilişkinin olmadığı belirlenmiştir. Bu araştırma kapsamında elde edilen nitel verilerin de nicel verileri desteklediği görülmüştür.

Anahtar Kelimeler: Değerlendirme Okuryazarlığı, Değerlendirme Okuryazarlığına İlişkin Öz-yeterlik Algısı, Öğretmen Adayı

\footnotetext{
*Bu çalışmanın bir bölümü 4th International Instructional Technologies \& Teacher Education Symposium (ITTES) 2016'da sözlü bildiri olarak sunulmuştur. Ayrıca bu çalışma danışmanlığı Sefa KAZANÇ tarafından yürütülen yüksek lisans tezinden üretilmiştir.

**Fırat Üniversitesi Eğitim Fakültesi, Matematik ve Fen Bilimleri Eğitimi Bölümü, Fen Bilgisi Eğitimi Anabilim Dalı. Doktora öğrencisi, oznurcambay@ hotmail.com

*** Prof. Dr. Fırat Üniversitesi Eğitim Fakültesi, Matematik ve Fen Bilimleri Eğitimi Bölümü, Fen Bilgisi Eğitimi Anabilim Dal1 / Elazı̆g.skazanc@firat.edu.tr
} 


\begin{abstract}
In this study utilizing the survey method, pre-service science, elementary and pre-school teachers' assessment literacy and self-efficacy about assessment literacy were investigated. The relationships between pre-service teachers' assessment literacy and self-efficacy about assessment literacy were also investigated. 105 4th grade preservice science teachers in the Department of Science Education Program (N=35), Elementary Teacher Education Program (N=35) and Pre-School Teacher Education Program (N=35) in Faculty of Education during 2015-2016 academic year participated in this study. The questionnaires and semi-structured individual interviews used to define the pre-service teachers' assessment literacy and self-efficacy about assessment literacy. Multivariate Analysis of Variance (MANOVA) and Pearson Correlation were used to evaluate the data obtained from the result of this study in order to investigate the pre-service teachers' assessment literacy and self-efficacy about assessment literacy. The statistical analyses of data revealed that there were statistically significance differences among the pre-service science, elementary and pre-school teachers as regards to the levels of assessment literacy and selfefficacy about assessment literacy $(\mathrm{p}<0.05)$. Furthermore, it was determined that there was no statistically significant correlation between assessment literacy and self-efficacy about assessment literacy of pre-service science, elementary and pre-school teachers ( $p>0.05$ ). The qualitative data obtained in the present study also supported the obtained quantitative data.
\end{abstract}

Keywords: Assessment Literacy, Self-Efficacy about Assessment Literacy, Pre-service Teachers

\title{
1.GIRIŞ
}

Değerlendirme, öğrenme-öğretme sürecinin etkili olup olmadığını belirlemek amacıyla yapılan, eğitim ve öğretimle ilgili verilerin toplanmasını ve yorumlamasını içeren çok adımlı, sistematik bir süreçtir (Milli Eğitim Bakanlığı [MEB], 2006). Öğretim programında belirtilen kazanımlara ne derece ulaşıldığı, öğrenme-öğretme süreci içerisinde yapılan etkinliklerin, uygulanan yöntem ve tekniklerin ne kadar başarılı olduğu ve öğrencilerin sahip olduğu bilgilerini nasıl ve ne şekilde yapılandırdığını belirlemekte değerlendirme aşamasının çok önemli bir basamak olduğu belirtilmektedir (İşman ve Eskicumalı, 2003). Günümüzde, eğitim-öğretim sürecinde araştırma-sorgulamaya dayalı öğrenme yaklaşımı doğrultusunda öğretmen merkezli bir değerlendirmeden öğrenci merkezli bir değerlendirme sistemine doğru gidilmektedir (MEB, 2013; 2017). Yani öğrencinin ölçme ve değerlendirme araçlarıyla hep aynı şekilde değerlendirildiği subjektif puanlama ile yürütülen bir süreçten, öğrencinin birçok yönden değerlendirilip değerlendirme sürecine aktif olarak katıldığı ve objektif puanlamanın yapıldığ bir değerlendirme sistemine geçiş söz konusudur (Stiggins, 2008). Ülkemizde yapılan çalışmalarda da, değerlendirme kavramı ile ilgili araştırmalara hız verildiği ve özellikle yapılandırmacı yaklaşıma paralel olarak öğrenciyi merkeze alıp değerlendiren yeni yaklaşım, yöntem, teknik ve araç-gereçlerle öğretim programlarının geliştirildiği görülmektedir. Hem ülkemizde hem de uluslararası alanda yapılan bu çalışmalarda, değerlendirme kavramı "değerlendirme okuryazarlı̆̆ı" adı altında yeniden tanımlanmaya başlanmıştır (Karaman, 2014; Mertler \& Campbell, 2005 gibi). Değerlendirme okuryazarlı̆̆ı, 
öğretmenlerin öğrencilerin birçok davranış ve becerilerini ölçmek için farklı değerlendirme yöntem ve tekniklerini bilmesi, tasarlayabilmesi, geliştirebilmesi, uygun analiz ve istatistiksel işlemleri uygulayabilmesi, elde edilen verileri yorumlayıp bir yargıya varabilmesi ve sonuçları paylaşabilmesi gibi belirli yeterliklere sahip olması şeklinde açıklanmıştır (Mertler \& Campbell, 2005). Değerlendirme okuryazarlı̆ğ iyi olan öğretmen ve öğretmen adaylarının, öğrencileri süreç içerisinde izleyebilmesi, öğrenme güçlüklerini belirleyerek giderebilmesi, öğrenme-öğretme sürecinde anlamlı ve kalıcı öğrenmeyi desteklemek amacıyla sürekli geri bildirim sağlayabilmesi gerekir. Ayrıca, ölçme sonucunda elde edilen sayısal değerlere anlam kazandırabilmeli, öğrencinin gelişimini izlemeli ve bu gelişime bağl1 olarak öğrenciyi yönlendirebilmelidir (MEB, 2013). Literatürde yapılan çalışmalarda da, değerlendirme okuryazarı olan öğretmen ve öğretmen adaylarının değerlendirmenin neden ve ne şekilde yapılması gerektiğini bilen, öğrenci seviyesine ve amacına en uygun ölçme ve değerlendirme yöntem ve araçgereçlerini seçebilen, geliştirebilen, kullandıkları ölçme araç-gereçlerinin geçerli ve güvenilir olmasına dikkat eden vb. birçok yeterliğe sahip olması gerektiği belirtilmiştir (Fulcher, 2012; Mertler ve Campbell, 2005). Ayrıca bu çalışmalarda, değerlendirme okuryazarı öğretmen ve öğretmen adaylarının öğretim sürecini daha iyi yönetip yürütebildikleri ve etkili öğrenmeler gerçekleştirdikleri vurgulanmaktadır.

Günümüzde öğretim programlarında "ürün kadar sürecin de değerlendirildiği” bir ölçme ve değerlendirme anlayışı benimsenerek, öğrenme-öğretme sürecinin sonunda öğrencinin ortaya koyduğu öğrenme ürünüyle birlikte gösterdiği performansın da değerlendirilmesi gerektiği belirtilmektedir (MEB, 2013, s.4). Bu bağlamda, bu öğretim programlarını uygulayacak öğretmen ve öğretmen adaylarının değerlendirme okuryazarlıklarının yüksek olması için değerlendirme okuryazarı bireyler olarak yetiştirilmesi gerekmektedir. Bunun için, öncelikle eğitim fakültelerinde yetiştirilen öğretmen adaylarının değerlendirme okuryazarlığı ve değerlendirme okuryazarlığına ilişkin öz-yeterlik algılarının belirlenmesi gerekmektedir. Literatürde, bu konuyla ilgili yapılan çalışmalarda öğretmen adaylarının değerlendirme okuryazarlık seviyeleri ve demografik özellikleriyle arasındaki ilişkileri, ölçme ve değerlendirmeye ilişkin düşünceleri, tutumları, yeterlikleri vb. incelenmiştir (Beziat \& Coleman, 2015; Gül, 2011; Karaman, 2014; Tao, 2014; Volante \& Fazio, 2007 gibi). S. Plake ve James Impara (1993) tarafından oluşturulan ve bu standartların her bir maddesini ayrı ayrı ölçecek çoktan seçmeli bir anket "Sınıfta Değerlendirme Okuryazarlığı Anketi” (CALi) geliştirilmiştir. Bu ankette 7 yeterlilik alanını ölçen, her bir yeterlilik anketini ölçen 5 alt madde ile toplamda 35 maddelik çoktan seçmeli bir ölçektir. Bu sınıfta değerlendirme okuryazarlık anketi ilk kez tüm özellikleri bakımında farklı yapıdaki 6 okulda, 555 öğretmene uygulanmıştır. Elde edilen verilerin analizinde, öğretmenlerin konu ile ilgili ölçmüş oldukları ölçme araçlarının sonuçlarını yorumlama, not verme gibi yeterlilik alanlarına sahipken; uygun metot seçme, tasarlama ve geliştirme gibi yeterlilik alanlarında düşük sonuçlar çıktığı gözlenmiştir (Plake, 1993). Mertler (2003), bu anketi öğretmen ve öğretmen adaylarına uygulayarak değerlendirme okuryazarlıklarını karşılaştırmış ve diğer çalışmalarda ortaya çıkan benzer sonuçlara varmıştır. Bu araştırma da 197 öğretmen ve 67 öğretmen adayına "Sınıfta Değerlendirme Okuryazarlığı Anketi" 
CALI'yi uygulamış ve istatiksel analizle verileri yorumlanmıştır. Bu çalışma sonucunda Mertler (2003), öğretmen adaylarının değerlendirme okuryazarlıkları yeterlik alanlarından uygun değerlendirme metodu seçmede en yüksek puanı aldığı gözlenmiştir. Yapılan çalışmada öğretmen ve öğretmen adayı karşılaştırıldığında, öğretmen adaylarının değerlendirme okuryazarlıklarında farklı yeterlilik alanları açısından farklı sonuçların olduğu görülmüştür.

Öz-yeterlik kavramı birçok meslekte ve alanda önemli olduğu kadar öğretmenlik mesleği için de oldukça önemli bir kavramdır. Öz-yeterlik inançlarının ne düzeyde olduğu öğretmenlerin istek, davranış ve hedeflerine bağlı olarak değişir. (Tschannen-Moran \& Hoy, 2001). Yılmaz, Köseoğlu, Gerçek ve Soran (2004)'a göre öğretmenlerin, alan bilgisi, pedagojik bilgi ve teknolojik bilgileri olmasıyla birlikte öz-yeterlik düzeylerinin de yeterli düzeyde olması gerektiğini ifade etmişlerdir. Öz-yeterlik inancı yüksek olan öğretmen ve öğretmen adayları sistemin tıkadığı olumsuzlukları kaldırmak, karşılaştıkları sorunları aşmak için daha çok çaba gösterip farklı çözüm yolları üretirler (Bandura 1977). Bu alanda yapılan birçok çalışma öz-yeterlik inancı düşük ve yüksek öğretmenler arasında kavram yanılgıları giderme, etkin ve aktif katılımı sağlama, teknolojileri kullanma, değerlendirme ölçme araçlarını tasarlama ve geliştirme, öğretim konusunda daha fazla sorumluluk alıp yerine getirme gibi noktalarda değişkenlik göstermiştir (Coladarci, 1992; Tschannen-Moran \& Hoy, 2001). Bu araştırmada ise, farklı branşlarda ki öğretmen adaylarının değerlendirme okuryazarlık düzeyleri ve değerlendirme okuryazarlıklarına yönelik öz-yeterlik algıları hem nitel hem de nicel yaklaşımlarla derinlemesine araştırılmıştır. Böylece, araştırmanın nitel ve nicel sonuçları doğrultusunda çeşitli önerilerde bulunularak literatüre önemli katkılar sağlanacağı düşünülmektedir.

$\mathrm{Bu}$ çalışmanın amacı, öğretmen adaylarının yeni bir oluşum olan değerlendirme okuryazarlığına karşı öz-yeterlik inançlarının ortaya çıkarılmasıdır. Değerlendirme okuryazar bir öğretmen olabilmek için değerlendirme araçları tasarlayabilme ve geliştirebilme inanc1, istatistiksel verilerle sonuçlara ulaşma inancı, elde edilen sonuçları yorumlama inancı gelişmiş olması gerekir. Aksi takdirde kendine inanc1, yapabileceğine inancı olmayan öğretmen ve öğretmen adaylarının başarılı bir öğrenme-öğretme sürecinden bahsedilemez. Ülkemizde özellikle birçok alanda öz-yeterlilik çalışması olmasına rağmen değerlendirme üzerine bu alanda çok az sayıda çalışma olduğu gözlenmektedir. Yapılan bu çalışmalara bakıldığında, öğretmenlerin genellikle MEB'in öğretmen kılavuzunda belirlemiş olduğu ya da yönlendirmiş olduğu kazanım testlerinden oluşan değerlendirme araçlarını kullandıklarından bahsedilmektedir. Bu nedenle, öğretmenlerde değerlendirmeye ilişkin öz-yeterlilik düzeylerinin yüksek çıktığı görülmektedir. Fakat aynı öğretmenlere amacına uygun bir ölçme aracı tasarlayabilir misiniz sorusuna bu konuda kendilerini yeterli hissetmedikleri belirlenmiştir. Öğretmenlerin değerlendirmeye karşı öz-yeterlik inançları ve tutumları verileri yorumlamada etkili olduğu vurgulanmıştır (Bonner ve Chen, 2009). Ayrıca birçok öğretmenin alternatif değerlendirme türlerinden habersiz olduğu ve hangi değerlendirme türlerini nasıl kullanacaklarını ve sisteme nasıl entegre edilmesi gerektiğini, alternatif ölçme değerlendirmede puanlamanın karışık ve objektif puanlamada kendini yeterli hissetmediklerini vurgulamışlardır. Bu çalışmada aşağıdaki sorulara cevap aranmıştır: 
1.Fen bilgisi, sınıf ve okul öncesi öğretmen adaylarının değerlendirme okuryazarlık seviyeleri nedir?

2. Fen bilgisi, sınıf ve okul öncesi öğretmen adaylarının değerlendirme okuryazarlık seviyeleri arasında istatistiksel olarak anlamlı bir farklılık var mıdır?

3.Fen bilgisi, sınıf ve okul öncesi öğretmen adaylarının değerlendirme okuryazarlığına ilişkin öz yeterlik algıları nedir?

4. Fen bilgisi, sınıf ve okul öncesi öğretmen adaylarının değerlendirme okuryazarlığına ilişkin öz yeterlik seviyeleri arasında istatistiksel olarak anlamlı bir farklılık var mıdır?

5.Fen bilgisi, sınıf ve okul öncesi öğretmen adaylarının değerlendirme okuryazarlık düzeyleri ve değerlendirme okuryazarlığına ilişkin öz-yeterlik algıları arasında istatistiksel olarak anlamlı bir ilişki var midır?

6.Fen bilgisi öğretmen adaylarının değerlendirme okuryazarlık düzeyleri ve değerlendirme okuryazarlığına ilişkin öz-yeterlik seviyeleri arasında istatistiksel olarak anlamlı bir ilişki var mıdır?

7.Sınıf öğretmen adaylarının değerlendirme okuryazarlık düzeyleri ve değerlendirme okuryazarlığına ilişkin öz-yeterlik seviyeleri arasında istatistiksel olarak anlamlı bir ilişki var mıdır?

8. Okul öncesi öğretmen adaylarının değerlendirme okuryazarlık düzeyleri ve değerlendirme okuryazarlığına ilişkin öz-yeterlik seviyeleri arasında istatistiksel olarak anlamlı bir ilişki var mıdır?

\section{YÖNTEM}

$\mathrm{Bu}$ çalışma, tarama modeline göre desenlenmiştir. Tarama modeli, var olan duruma müdahale etmeden olduğu gibi betimlemeyi amaçlamaktadır. Tarama modeli araştırmalarda evrenin tamamından ya da belli bir gruptan veriler toplanabilir. Gruptan elde edilen bilgiler çalışmanın verilerini oluşturur. Tarama modeli kullanılarak yapılan araştırmalarda durumun nedeninden çok değişkenler arasındaki ilişkinin belirlenmesi söz konusudur (Karasar, 2012). Dolayısıyla, bu araştırma ile tarama modeli kullanılarak dördüncü sınıf öğretmen adaylarının ölçme-değerlendirme alanındaki var olan durumları ve bu durumlara yönelik yeterlikleri betimlenmeye çalışılmıştır. Araştırma süresince hem nitel hem de nicel veri toplama teknikleri kullanılarak veriler elde edilmiştir. Bu veriler, bütüncül bir yaklaşımla yorumlanarak araştırma soruları cevaplandırılmıştır.

\section{Çalışma Grubu}

Bu araştırmaya, 2015-2016 öğretim yılı Frat Üniversitesi Eğitim Fakültesi Matematik ve Fen Bilimleri Eğitimi bölümünde Fen Bilgisi Eğitimi Anabilim Dalı ile Temel Eğitim bölümlerindeki Sınıf ve Okul Öncesi Eğitimi Anabilim Dalı'nda öğrenim gören 4. sınıfa devam eden 35'er kişilik toplamda 105 öğretmen adayı katılmıştır. Örneklemin 4. sınıf öğrenimine devam eden öğretmen adaylarından seçilmesinin sebebi, öğretmen adaylarının ölçme ve değerlendirme dersinin 4. sınıfta tamamlamış 
olmaları ve okul deneyimi dersindeki ölçme-değerlendirme tecrübelerine dayanarak verilerin toplanmasıdır. Öğretmen yetiştirme programlarının ölçme-değerlendirme konusundaki başarısının tespit edilmesi için, çalışmaya katılan öğretmen adaylarının programda verilen ölçme-değerlendirme dersini almış olmaları gerekmektedir. Dolayısıyla seçilen örneklem türü, amaçsal örneklem (purposeful sampling) yöntemlerinden biri olan ölçüt örneklemidir (criterion sampling).

\section{Veri Toplama Süreci ve Veri Toplama Aracı}

$\mathrm{Bu}$ çalışmada, veri toplama aracı olarak Campell ve Mertler (2005) tarafindan geliştirilmiş, Türkçe 'ye Bütüner ve diğerleri ( 2010) tarafindan uyarlanmış Ölçme-Değerlendirme Okuryazarlığ Envanteri (ÖDOE) ile Kılınç (2011)'ın geliştirmiş olduğu Eğitimde Ölçme ve Değerlendirmeye Yönelik Öz-Yeterlik Algı Ölçeği (EÖDÖA) ve bireysel yarı-yapılandırılmış mülakatlar kullanılmıştır.

Araştırmada, öncelikle 35'er fen bilgisi, sınıf ve okul öncesi öğretmen adaylarına ÖDOE ve EÖDÖA uygulanmıştır. Sonra öğretmen adayları arasından rastgele seçilen 15'er öğretmen adayıyla ortalama 45 dakika süren bireysel yarı-yapılandırılmış mülakatlar yapılmıştır (Tablo 1). Mülakat süresince yapılan tüm görüşmeler ses kayıt cihazı ile kayıt altına alınmıştır. Bu veri toplama sürecinin daha sağlıklı bir şekilde yürütülmesi için ölçme araçları uygulanırken, öğretmen adaylarının kendi aralarındaki etkileşimin minimum düzeye indirilip, birbirinden bağımsız bir şekilde soruları cevaplandırmaları sağlanmıştır.

Tablo 1. Araştırmada Veri Toplama Sürecine Katılan Öğretmen Adaylarının Branşlara Göre Dağı̆lımı

\begin{tabular}{lcc}
\hline & Bölüim & $\mathbf{N}$ \\
\hline \multirow{2}{*}{ Nicel Veri } & Fen Bilgisi Eğitimi & 35 \\
& Sinıf Eğitimi & 35 \\
& Okul Öncesi Eğitimi & 35 \\
\cline { 2 - 3 } & Toplam & 105 \\
\hline \multirow{2}{*}{ Nitel Veri } & Fen Bilgisi Eğitimi & 15 \\
& Sinıf Ĕgitimi & 15 \\
& Okul Öncesi Eğitimi & 15 \\
\cline { 2 - 3 } & Toplam & 45 \\
\hline
\end{tabular}

Araştırmaya katılan öğretmen adaylarının değerlendirme okuryazarlıklarını belirlemek için, Campell ve Mertler'in (2004) geliştirdiği ÖDOE kullanılmıştır. Bu envanter, MEB'in ölçme ve değerlendirmeye ilişkin yeterlik alanları temel alınarak Bütüner, Yiğit ve Odabaşı Çimer (2010) tarafından Türkçe'ye çevrilip geliştirilmiştir. ÖDOE, 5 senaryo ve her senaryo ile ilgili 6 soru olmak üzere 30 maddeden oluşmaktadır. ÖDOE’nin Cronbach Alpha katsayısı 0,82 olarak hesaplanmıştır. Fen bilgisi, sınıf ve okul öncesi öğretmen adaylarının değerlendirme okuryazarlığına ilişkin öz-yeterliklerini belirlemek için de, 5'li likert bir ölçek olan EÖDÖA kullanılmıştır. Kılınç (2011) tarafından geliştirilen bu ölçek, 23 maddeden oluşmaktadır. EÖDÖA, öğretmen adaylarının eğitimde ölçme ve 
değerlendirmeyle ilgili bilgi ve becerilerine ilişkin öz-yeterliklerini ölçebilecek nitelikte oluşturulmuştur (Kılınç, 2011). EÖDÖA’nin Cronbach Alpha katsayısı 0,96 olarak hesaplanmıştır.

Fen bilgisi, sınıf ve okul öncesi öğretmen adaylarının değerlendirme okuryazarlığına ve değerlendirme okuryazarlığına ilişkin öz-yeterliklerine yönelik görüşlerini derinlemesine ortaya çıkarmak için, bireysel yarı-yapılandırılmış mülakatlar yapılmıştır. Mülakat soruları, ölçme ve değerlendirmeye ilişkin öğretmenlerin sahip olması gereken MEB'in belirlemiş olduğu yeterlik alanları (MEB, 2006), ÖDOE ve EÖDÖA anketlerinde bulunan sorularla paralellik göstermektedir.

Ayrıca mülakat soruları, öğretmen adaylarının anketlere verdikleri cevapların nedeni, cevaplayamadıkları anket soruları ve adaylarda var olan kavram yanılgıları da dikkate alınarak oluşturulmuştur. Mülakat soruları aşağıdaki gibidir:

1. Ölçme ve Değerlendirme nedir? Ölçme ve değerlendirme arasındaki fark nedir?

2. Değerlendirme yaklaşımları nelerdir? Siz kendi derslerinizde hangi değerlendirme yaklaşımlarını kullanırdınız? Sizce en etkili yaklaşım hangisidir?

3. Sizce, ders sonunda ya da ders sürecinde öğrencinin aldığı puanlar öğrencinin ne öğrendiğini ne derece yansitır?

4. Öğrenme- öğretme sürecinde değerlendirme sonucunda elde ettiğiniz verileri analiz edip yorumlama, öğrenme-öğretme süreci içerisinde öğrencilerin gelişimi, öğrencilerin öğrenmelerine ilişkin geri bildirim (dönüt) sağlama ve öğretimin değerlendirilmesi konusunda neler söyleyebilirsiniz.

\section{Verilerin Analizi}

Fen bilgisi, sınıf ve okul öncesi öğretmen adaylarının değerlendirme okuryazarlık düzeyleri ve değerlendirme okuryazarlığına ilişkin öz-yeterlik algılarına ilişkin elde edilen nicel verileri analiz etmek için, Çok Değişkenli Varyans Analizi (MANOVA) kullanılmıştır. Bağımsız değişkenlerden (fen bilgisi, sınıf ve okul öncesi öğretmen adayları) alınan örneklem ile bakılan histogram grafiği, verilerin normal dağılım gösterdiğini ortaya koymuştur. Kolmogorov-Smirnov testi ve Shapiro-Wilk testi sonuçlarının istatistiksel olarak anlamlı çıkmaması ( $\mathrm{p}>.05)$ histogram grafiklerinden elde edilen sonucu desteklemiştir. Normal dağılım gözlenmesi ile verilerin analizinde parametrik (MANOVA) istatistik testlerinin kullanılması uygun bulunmuştur.

Araştırmaya katılan öğretmen adaylarının bireysel yarı-yapılandırılmış mülakatlarından elde edilen nitel veriler ise, içerik analizi yöntemiyle analiz edilmiştir. Araştırma verileri alanında uzman iki araştırmacı tarafından ayrı ayrı gruplandırıldıktan sonra ortaya çıkan kategori listesine son şekli verilmiştir. Kategori listesindeki temalar iki araştırmacı tarafından kategori listesine göre değerlendirilmiştir. Araştırmacıların birbirinden bağımsız olarak kullandıkları kategorilerin tutarlılığı “Görüş birliği” ya da "Görüş ayrılı̆̆ı” şeklinde işaretlemeler yapılarak belirlenmiştir. Bu şekilde yapılan veri analizinin güvenirliği, [Görüş birliği / (Görüş birliği + Görüş ayrılığı) x 100] formülü kullanılarak hesaplanmıştır (Miles ve Huberman, 1994). Kodlayıcılar arasındaki ortalama güvenirlik \% 82 olarak bulunmuştur. Mülakat soruları, ‘Ölçme ve değerlendirme bilgisi, Ölçme ve Değerlendirme Yöntem ve Tekniklerini belirleme ve geliştirme, Verileri analiz ederek yorumlama, öğrencinin gelişimi ve 
öğrenmesi hakkında geri bildirim sağlama, Uygun derecelendirme ölçme araçlarını (rubrik) seçme, yöntemlerini geliştirme, tasarlama konusunda kendini yeterli hissetme'” temaları altında toplanmıştır.

\section{BULGULAR}

Öğretmen adaylarının değerlendirme okuryazarlığı ve değerlendirme okuryazarlığına ilişkin özyeterlik algılarıyla ilgili nitel ve nicel bulgular aşağıda verilmiştir.

Tablo 2'de değerlendirme okuryazarlığı ve değerlendirme okuryazarlığına ilişkin öz-yeterlik grubuna ait MANOVA analizi sonuçları sunulmuştur. MANOVA analizinden elde edilen sonuçlar, gruplar arasında istatistiksel olarak anlamlı bir farklılığın olduğunu göstermiştir (Wilks' $\lambda=0.755 \underline{\mathrm{F}}=$ 7.661, $\mathrm{p}=0.000)$.

Tablo 2. MANOVA Sonuçları

\begin{tabular}{ccccccc}
\hline & & Değer & F & Hipotez sd & Hata df & P \\
\hline \multirow{2}{*}{ Grup } & Wilks' Lambda & 0.755 & 7.661 & 4.000 & 202.000 & 0.000 \\
\hline
\end{tabular}

MANOVA analizinin ardından, gruplar arasında her bir bağımlı değişkene ilişkin istatistiksel olarak anlamlı bir farklılı̆̆ın olup olmadığını belirlemek için ANOVA analizi yapılmış ve elde edilen sonuçlar Tablo 3'de sunulmuştur.

Tablo 3. Araştırmaya Katılan Öğretmen Adaylarının Değerlendirme Okuryazarlık ve Değerlendirme Okuryazarlığına İlişkin Öz-Yeterliklerine İlişskin ANOVA Sonuçları

\begin{tabular}{|c|c|c|c|c|c|c|}
\hline $\begin{array}{c}\text { Varyansın } \\
\text { Kaynağı }\end{array}$ & Bağımlı Değişken & $\begin{array}{c}\text { Kareler } \\
\text { Toplamı }\end{array}$ & Sd & $\begin{array}{c}\text { Kareler } \\
\text { Ortalaması }\end{array}$ & $\mathbf{F}$ & $\mathbf{P}$ \\
\hline \multirow{2}{*}{ Grup } & Değ. Okuryazarlık & 329.200 & 2 & 164.600 & 11.662 & 0.000 \\
\hline & Öz-yeterlik & 5.001 & 1 & 1315.32 & 4.350 & 0.000 \\
\hline \multirow{2}{*}{ Hata } & Değ. Okuryazarlık & 1439.600 & 102 & 14.111 & & \\
\hline & Öz-yeterlik & 58.630 & 102 & .575 & & \\
\hline \multirow{2}{*}{ Toplam } & Değ. Okuryazarlık & 1768.800 & 104 & & & \\
\hline & Öz-yeterlik & 63.631 & 104 & & & \\
\hline
\end{tabular}

Tablo 3 incelendiğinde, fen bilgisi, sınıf ve okul öncesi öğretmen adaylarının değerlendirme okuryazarlıkları arasında anlamlı bir farklılığın olduğu görülmektedir [F=11,662 p=0,000]. Bu anlamlı farklılığın hangi gruplar arasında olduğunu tespit etmek için yapılan Post Hoc testlerinden LSD testi sonuçları, fen bilgisi öğretmen adayları ile okul öncesi öğretmen adayları arasında istatistiksel olarak anlamlı farklılık bulunmamıştır ( $>>0.05$ ). Fen bilgisi, sınıf ve okul öncesi öğretmen adaylarının özyeterlik düzeyleri arasında da anlamlı bir farklılığın olduğu görülmektedir $[F=4,350, p=0,000]$. Post Hoc 
testlerinden LSD testi sonuçlarına göre, sınıf öğretmen adaylarının fen bilgisi ve okul öncesi öğretmen adayları ile istatistiksel olarak anlamlı farklılık olduğunu göstermektedir $(\mathrm{p}<0,05)$. Fakat fen bilgisi ögretmen adayları ile okul öncesi öğretmen adayları arasında istatistiksel olarak anlamlı farklılık bulunmadığı gözlenmiştir ( $\mathrm{p}>0,05)$.

Tablo 4. Öğretmen Adaylarının Branş Değişkenine Göre Değerlendirme Okuryazarlık Düzeylerini Gösteren LSD Testi İstatistik Sonuçları

\begin{tabular}{|c|c|c|c|}
\hline Bağımlı Değişkenler & Grup & Farkların Ortalaması & $\mathbf{P}$ \\
\hline \multirow{3}{*}{$\begin{array}{l}\text { Değerlendirme } \\
\text { Okuryazarlığı }\end{array}$} & FBÖA-SÖA & 2.54 & .006 \\
\hline & FBÖA-OÖÖA & 1.77 & .051 \\
\hline & SÖA-OÖÖA & 4.31 & .000 \\
\hline \multirow{3}{*}{ Öz-yeterlik } & FBÖA-SÖA & 2.54 & .006 \\
\hline & FBÖA-OÖÖA & 1.77 & .056 \\
\hline & SÖA-OÖÖA & 4.31 & .000 \\
\hline
\end{tabular}

Tablo 4’teki bulgulara göre sınıf öğretmen adayları ile fen bilgisi ve okul öncesi öğretmen adayları arasında istatistiksel olarak anlamlı farklılık olduğu görülmektedir $(\mathrm{p}<0.05)$. Bu fark sınıf öğretmeni adaylarının lehinedir.

Tablo 5. Öğretmen Adaylarının Değerlendirme Okuryazarlığı ve Değerlendirme Okuryazarlığına İlişkin ÖzYeterliklerine İlişkin Ortalama ve Standart Sapma Puanları

\begin{tabular}{ccccc}
\hline Bağımlı değişkenler & Grup & $\mathbf{N}$ & Standart Sapma & Ortalama \\
\hline \multirow{2}{*}{$\begin{array}{c}\text { Değerlendirme } \\
\text { Okuryazarlığı }\end{array}$} & FBÖA & 35 & 3.88 & 10.94 \\
\cline { 2 - 5 } & SÖA & 35 & 3.148 & 13.48 \\
\cline { 2 - 5 } & OÖÖA & 35 & 4.16 & 9.33 \\
\cline { 2 - 5 } Öz-yeterlik & FBÖA & 35 & .16 & 3.06 \\
\cline { 2 - 5 } & SÖA & 35 & .12 & 2.54 \\
\hline
\end{tabular}

FBÖA: Fen Bilgisi Öğretmen Adayı $\quad$ SÖA: Sınıf Öğretmen Adayı $\quad$ OÖÖA: Okul Öncesi Öğretmen Adayı

$\mathrm{Bu}$ çalışmada bireysel yarı-yapılandırılmış mülakatlara katılan fen bilgisi, sınıf ve okul öncesi öğretmen adaylarına değerlendirme okuryazarlığıyla ilgili birçok açık uçlu soru yöneltilmiştir. Mülakatlara katılan öğretmen adaylarının, değerlendirme okuryazarlığına yönelik sahip olduğu bilgilerine bakıldığında okul öncesi öğretmen adaylarının diğer öğretmen adaylarına göre değerlendirme bilgilerinin daha yüzeysel olduğu ve değerlendirme okuryazarlığına ilişkin teorik bilgilerini uygulamada kendilerini daha az yeterli hissettikleri görülmüştür. Değerlendirme okuryazarlığına ilişkin öz-yeterlik anketinde sınıf öğretmen adaylarının ortalama puanı 3.54 iken okul öncesi öğretmen adaylarının 2.67 'dir. Öğretmen adaylarına ait ortalama puanların verildiği Tablo 5'e göre, sınıf öğretmenliği 
bölümünde öğrenim gören öğretmen adaylarının değerlendirme okuryazarlık ortalamaları fen bilgisi ve okul öncesi öğretmen adaylarına göre daha iyi oldukları anlaşılmaktadır. Çünkü değerlendirme okuryazarlı̆ğ envanterin de sınıf öğretmen adaylarının ortalama puanı 13,48 iken, okul öncesi öğretmen adaylarının ortalama puanı 9.33'dür.

Yapılan mülakatlar sonucunda öğretmen adaylarının görüşlerinden bazı örnekler aşağıda sunulmuştur:

Tablo 6. Öğretmen Adaylarının Ölçme- Değerlendirme Bilgisine Yönelik Görüşleri

\begin{tabular}{llccc}
\hline & & Branşlar & f & \% \\
\hline \multirow{3}{*}{$\begin{array}{l}\text { Ölçme } \\
\text { bilgisi }\end{array}$} & ve değerlendirme & FBÖA & 10 & 67 \\
\cline { 3 - 5 } & & SÖA & 9 & 60 \\
\cline { 2 - 5 } & & Ö̈ÖA & 6 & 40 \\
\hline
\end{tabular}

$\mathrm{Bu}$ çalışmanın nitel veri toplama sürecinde, fen bilgisi, sınıf ve okul öncesi öğretmen adaylarının değerlendirme okuryazarlığı ve değerlendirme okuryazarlığına ilişkin öz-yeterlikleriyle ilgili bireysel yarı-yapılandırılmış mülakatlar yapılmıştır. Buna göre; 10 (\%67) fen bilgisi, 9 (\%60) sınıf ve 6 (\%40) okul öncesi öğretmen adayı ölçme ve değerlendirmenin tanımı, ölçme ve değerlendirme kavramları arasındaki farkı belirtmiştir.

Araştırmacı: Değerlendirme nedir? Ölçme nedir? Değerlendirme ve ölçme arasındaki fark nedir?

FBÖA1: Ders sonunda konu ile ilgili öğrencilere sorular yöneltmek ölçme; sorulara karşı verilen cevapların yorumlanıp bir yargıya bağlanması değerlendirmedir... Sayısal veri ölçmedir, sayısal verinin yorumlanıp yargıya varılması değerlendirmedir diyebiliriz...

SÖA10: Herhangi bir konu ya da ünite ile ilgili sorular yöneltilmesi sayı ve sembollerle belirtilmesi ölçmedir. Bu sayl ve sembollerin yorumlanması değerlendirmedir. Örneğin, Ahmet' in boyu $60 \mathrm{~cm}$ demek ölçme Ahmet'in boyu diğger arkadaşlarından kısadır demek değerlendirmedir.

OÖÖA3: Örneğin, bir çocuğun boyunu metre ile belirlenmesi yani boyunun 1.10 olması ölçme; boyunun uzun ya da kısa olarak tabir edilmesi değerlendirmedir. 
Tablo 7. Öğretmen Adaylarının Ölçme ve Değerlendirme Yöntem ve Tekniklerini Belirleme ve Geliştirmeye Yönelik Görüşleri

\begin{tabular}{lccc}
\hline & Branşlar & $\mathbf{f}$ & \% \\
\hline & FBÖA & 8 & 53 \\
\cline { 2 - 4 } Ölçme ve Değerlendirme Yöntem ve & SÖA & 8 & 53 \\
Tekniklerini Belirleme ve geliştirme & OÖÖA & 4 & 26 \\
\hline
\end{tabular}

Tablo 7’ye göre, 8 (\%53.33) fen bilgisi, 8 (\%53.33) sınıf ve 4 (\%26.67) okul öncesi öğretmen adayına değerlendirme yaklaşımları (geleneksel, alternatif ve otantik), değerlendirme yöntem ve tekniklerinin neler olduğu sorulmuş ve uygun ölçme -değerlendirme yöntem ve tekniklerini belirleme konularında kısmen yeterli açıklamalarda bulunmuşlardır. Her alandaki diğer öğretmen adayları ise ölçme-değerlendirme yöntem ve tekniklerini bilmediklerini ya da değerlendirme metotlarını seçmede sıkıntı yaşadıklarını belirtmişlerdir. Ayrıca 4 (\%26.67) okul öncesi öğretmen adayı da, öğrencilerini değerlendirmek için öğretmen kılavuz kitabının sonundaki hazır ölçme araçları şablonlarını kullanacaklarını söylemişlerdir.

Araştırmacı: Değerlendirme yaklaşımları nelerdir? Hangi değerlendirme yaklaşımını kullanırdınız? Sizce en etkili yaklaşım hangisidir?

FBÖA5: Stajda danışman hocamdan gözlediğim kadarılla fen dersleri oyun olarak geçmekte drama, köşeleme, kartopu, çember gibi teknikleri kullanıyor danışman hocam ve değerlendirme de anlık verilen cevaba göre süreç içerisinde oluyor. Bence en etkili yöntem alternatif değerlendirme bende öğretmen olup mesleğimi icra edersem alternatif değerlendirmeyi kullanırım.

SÖA5: Geleneksel alternatif diye biliyorum. Ya değerlendirme hakkında doğru düzgün bir şey bilmiyorum öğretmen olursam bende klasik yöntemler kullanırım. Teorik ölçme değerlendirme aldık ama unuttum. Yazılı, sözlü, test yaparım bende ögretmen olursam...

OÖÖA2: Okul öncesinde ölçme ve değerlendirme genel olarak ögrencilerle bire bir, küçük grup veya büyük grup içinde çalışma ve onların düşünme, problem çözme, tasarlama, planlama ve uygulama süreçlerinin gözlemlerine dayanır. Okul öncesi ögretmenliğinde daha çok portfolyo ve gözlem formu kullanılır bende bu teknikleri kullanirım.

Araştırmacı: Öğrenme-öğretme ortamında ölçme-değerlendirme araç-gereçleri nasıl geliştiriyorsunuz? Ölçme-değerlendirme araç gereçleri kullanırken nelere dikkat ediyorsunuz? 
FBÖA3: ölçme değerlendirme dersi en zorlandı̆̆ım derstir. Derste hocam bir anket gelişstirmemizi istemişti uzun ve zor bir süreçti aynı işlemler bir sınav içinde geçerli olur mu bilmiyorum ama ölçek geliştiremem. Bu yüzden öğretmen olduğumda puanlaması kolay öğrencinin öğrenip öğrenmediğini net gözlemleyebileceğim ölçme araçları kullanacă̆ım. Stajda ögrencinin ön bilgilerinde almada süreç ve sonuçta TAGA, kavram haritası, kavram karikatürü, vee diyagramı, tanılayıcı dallanmıs ă̆aç gibi puanlama türü kolay, davranışı net ölçen ölçme araçları kullanıyorum.

SÖA5: ben yüzeysel araç-gereç gelişstirebilirim. Fakat ölçme değerlendirme kurallarına göre geçerlilik ve güvenirlik yaparak bir ölçek geliştireceğimi ya da sınav yapacağımı düşünmüyorum. Değerlendirme olarak, uygulama ve puanlama süreçleri daha kolay olduğu için sınıfların kabalalık olmasından dolayı daha çok geleneksel sinav sistemlerini kullanacă̆ımı düşünüyorum.

SÖA9: ölçme değerlendirme yaparken genellikle alternatif ölçme araçlarını kullanacă̆ımı düşünüyorum sinıf ögretmenliği temel eğitim olduğu için somut dönemi kapsadı̆̆ından dolayı biraz daha ĕglenceli bulmacalar, resimli diyalog şeklinde değerlendirme, kavram karikatürü, zihin haritaları şeklinde ölçme araçlarını ileride meslek hayatına geçtiğimde kullanacă̆ım.

OÖA13: Ölçme değerlendirme noktasında zayıfim. Değerlendirme olarak geleneksel değerlendirme yaklaşımlardan kullanacağım. Özelikle gözlem yoluyla soru cevap şeklinde dĕgerlendirme yapacă̆ım

Araştırmacı: Değerlendirme yapılırken nasıl bir süreç izlenmelidir? Nelere dikkat edilmeli ve hangi kriterlere uygun davranılmalıdır?

FBÖA5: Ders sonunda konu ile ilgili olmalıdır. Ünitenin tüm konularını kapsayacak şekilde olmalıdır... Değerlendirme bu zamana kadar almış olduğum eğitimde hep ünite sonunda yazılı sınavlar veya test olduk, değerlendirme yapılırken soruların zorluk ve kolaylık derecelerine göre hazırlanmalıdır...

SÖA1: Bence değerlendirme yapılırken ders içeriğine paralel şekilde olmalıdır. Değerlendirme sadece sonuca yönelik değil süreç içerisinde de değerlendirme olmalıdır. Öğrenci süreçte değerlendirilirken öğrencinin gelişim ve performansı ele alınarak değerlendirme yapılmalıdır. Tarafsızlık ve objektiflik yanlı ya da duygusal davranarak puan verilmemelidir. Özelikle de her ögrencinin öğrenmesi farklı olduğu gibi değerlendirme türleri de farklı olmalıdır. Yani bazı ögrenciler sözel ifadesi iyiyken bazılarınınsa yazıya aktarımı iyidir bu yüzden öğrencileri çok yönlü yorumlayacak bir değerlendirme ölçme aracı geliștirilmelidir... 
Araştırmacı: Öğrenciyi çok yönlü yorumlayacak nasıl değerlendirme, ölçme araçları olabilir?

SÖA1: Yani öğrencinin gelişimini, ne öğrendiği nasıl öğrendiğini gösterecek gelişimini basamaklara ayıracak ögrencinin nerden nereye geldiğini gösterecek bir ölçme aracı olabilir buda portfolyo, problem çözme ödevleri proje tarzı ölçme araçları olabilir...

SÖA12: Bence değerlendirme yapılırken ölçme değerlendirme dersinde gördüğ̈̈müz kadarlyla kullanilan yöntem ve tekniğe göre değerlendirme araçlar belirlenmelidir. Örneğin, anlatım yoluyla öğretmen sürekli anlatıyorsa soru cevap şeklinde öğrenmenin gerçekleşip gerçekleşmediğini kontrol edebilir. Fakat öğrenci ders sürecinde aktifse öğrenci öz ve akran değerlendirme ile değerlendirilebilir.

OÖÖA6: Değerlendirme kriterleri olarak MEB tarafindan belirlenen şablonlar kullanıllyor. Özellikle okul öncesinde değerlendirme diğer branşlar da olduğu gibi derinlemesine bir değerlendirme yoktur öğrencinin tuvalet alışkanlı̆̆ diş firçalama alışkanlığı gibi günlük hayatta kendi ihtiyaçların yerine getirebilecek şekilde eğitimler verdiğimiz için diğer branşlardaki gibi bir değerlendirme söz konusu değildir daha asgari düzeyde bir değerlendirme söz konusudur...

Tablo 8. Öğretmen Adaylarının Verileri Analiz Ederek Yorumlama, Geri bildirim Sağlamaya Yönelik Görüşleri

\begin{tabular}{lccc}
\hline & Branşlar & F & \% \\
\hline & FBÖA & 7 & 46 \\
\cline { 2 - 4 } $\begin{array}{l}\text { Verileri analiz ederek yorumlama, öğrencinin } \\
\text { gelişimi ve öğrenmesi hakkında geri bildirim }\end{array}$ & SÖA & 6 & 40 \\
\cline { 2 - 4 } sağlama & OÖA & 3 & 20 \\
\hline
\end{tabular}

Fen bilgisi öğretmen adaylarından 7 (\%46.67)'si, sınıf öğretmen adaylarından 6 (\%40)'s1 ve okul öncesi öğretmen adaylarından 3 (\%20)'ü elde ettikleri verileri analiz edip yorumlama, öğrenmeöğretme süreci içerisinde öğrencilerin gelişimi, öğrencilerin öğrenmelerine ilişkin geri bildirim (dönüt) sağlama ve öğretimin değerlendirilmesi konularında kısmen yeterli açıklamalarda bulunmuşlardır. Örneğin, fen bilgisi ve sınıf öğretmen adayları öğrencilerin neler öğrenip öğrenmediklerini analiz edip yorumlamada ve öğrenci gelişim düzeylerini görmede alternatif değerlendirme araçlarını kullanmanın ve süreç değerlendirme yapmanın önemini vurgulayarak bu noktada etkili olduğunu belirtmişlerdir. Okul öncesi öğretmen adayları ise öğrencilerin kazanması gereken davranışları öğrenip öğrenmediğini özellikle süreç değerlendirmeler yaparak belirleyebileceğine ve buna bağlı olarak öğrencinin gelişimini 
yorumlayabileceğine ilişkin açıklamalar yapmışlardır. Geriye kalan fen ve sınıf öğretmen adayları, puanlama ve yorumlama kısmında herhangi bir sıkıntı yaşamadıklarından bahsetmiş̧lerdir. Çünkü puanlama ve yorumlamada, geleneksel değerlendirme yaklaşımı doğrultusunda ölçme araçlarını kullandıkları için puanlamanın daha kolay olduğunu ve alınan puan aralığının neye denk geldiğini yorumlamada kolaylık sağladığını söylemişlerdir. Ayrıca bu öğretmen adayları, alternatif ve otantik değerlendirmede bilgi ve beceri veya performans puanlama sürecinin karmaşı olduğunu ve objektif bir değerlendirme yapmanın zor olacağını belirterek, bu değerlendirme yaklaşımlarını kullanmada sıkıntı yaşayacaklarını ifade etmişlerdir. 3 fen bilgisi ve 4 sınıf öğretmen adayı ise bu nedenlerden dolayı bu değerlendirme yaklaşımlarını öğretmen olduklarında kullanmayacaklarını belirtmişlerdir. Okul öncesi öğretmen adaylarından 8 (\%53.33)'ü de, öğretmen kılavuz kitabının sonundaki hazır ölçme aracı olan kazanım değerlendirme şablonlarını kullanacaklarını ve kendilerine göre puanlama yaptıklarını söylemişlerdir.

Araştırmacı: Öğrenme- öğretme sürecinde değerlendirme sonucunda elde ettiğiniz verileri analiz edip yorumlama, öğrenme-öğretme süreci içerisinde öğrencilerin gelişimi, öğrencilerin öğrenmelerine ilişkin geri bildirim (dönüt) sağlama ve öğretimin değerlendirilmesi konusunda neler söyleyebilirsiniz?

FBÖA2:Öğrenme süreci içerisinde öğrencilerin davranışlarını, ne öğrenip ögrrenmediklerini ölçmek için alternatif ölçme değerlendirme araçlarını kullanırım. Öğrenciyi süreç ve sonuç olarak iki ayrı durumda değerlendirmek gerekir. Süreç değerlendirmesi yaparken sadece soru-cevap şeklinde olmamall. Sonuç değerlendirme de ise ögrencileri sinav yaptı̆̆ımızda öğrenci ürünlerini yorumlamada sorun yaşamayacağımı düşünmüyorum.

SÖA5:Öğrencilerimin ne öğrendiğini ögrrenilen bilginin nasıl kalıcı olduğu ortaya koymak için geleneksel değerlendirme araçlarını kullanırım. Alternatif ölçme araçlarını puanlama ve yorumlama kısmı bana göre oldukça karmaşıktır. Fakat geleneksel ölçme araçlarını yorumlamak nicel bir puan elde etmek soruya göre verilen cevabın bir puan aralı̆gını olması puanlamayı ve analiz etme sürecini kolaylaştırdı̆̆ için geleneksel ölçme değerlendirme yolunu kullanacağım.

SÖA15:Alternatif ve otantik değerlendirme süreci puanlama analiz süreci bana göre karışıktır. Öğrenci davranışını ölçerken bana göre pek fazla objektif olunacağını düşünmüyorum. Bazen öğrenme gerçekleşmiş midir? İstenilen davranışı ölçülmüss müdür? Alternatif ölçme değerlendirme bana göre performansa dayalı olduğu için tarafsız bir değerlendirmenin olması mümkün değildir. Öğretim değerlendirmesi öğrencinin öğrenip öğrenmediğini sorgulamaktır. Sinavlar sonucu elde edilen puanların yansımasıdır. 
OÖA12:MEB'in ön gördüğü hazır ölçme değerlendirme araçlarını kullanırım gözlem formu gibi hazır şablonlar var zaten MEB bizi yönlendiriyor kllavuz kitabında belirtilen ölçme araçlarını kullan diye.

Araştırmacı: Süreç değerlendirmesi mi yoksa sonuç değerlendirmesi mi yaparsınız? Süreç ya da sonuç değerlendirmesi yaparken nasıl bir süreç izlersiniz?

FBÖA13: Ölçme değerlendirme dersinde gördü̆̆̈̈müz kadarlyla her ikisi de olmalı ögrrenci hem süreç içerisinde hem de sonuçta değerlendirilmelidir. Dersin her basamağında öğrenilen bilginin kavranması için dönüt düzeltme yapılmalıdır...

SÖA5: Ölçme değerlendirme dersinde teorik olarak gördügümüz kadarlyla dersin her basamağında değerlendirme yapılmalıdır. Çünkü öğrenci her basamakta konu ile ilgili bir şeyler öğrenmektedir. Öğrenilen her bilgiye dönüt verilmelidir...

OÖÖA7: Öğrenci her an değerlendirmeye tabi tutulmalıdır. Özellikle okul öncesi yaş grubundaki öğrenciler keşfetmeye daha çok müsait olduğu için zaten onlar soru yöneltiyorlar okul öncesinde sonuç değerlendirmesi söz konusu değildir...

Araştırmacı: Sizce, ders sonunda ya da ders sürecinde öğrencinin aldığı puanlar öğrencinin ne öğrendiğini ne derece yansıtır?

FBÖA8: Bence ders sonunda ve ders sürecinde ögrencinin aldı̆̆ puan ne öğrendiğini yansıtmaz. Ben ders sürecinde öğrenciye bir kavramı soruyorum söylüyorken diğer kavram için yorum yapamıyor. Yani bazen bildiği yerden çıkar bazen her şeyi bilirken bir kavramımı bilmemesiyle hiçbir şey bilmiyor anlamına gelmez...

SÖA12: Okullarda staja gittiğimizde gördüğümüz öğrencinin aldĭ̆ puan öğrencinin ne öğrendiğini yansıtmaz. Çünkü bana göre hazırlanan ölçme araçlarının hemen hemen hepsi tüm üniteyi kapsayan sorulardan oluşmaz. Öğrencinin iyi bildiği yerlerden gelir ya da üniteye hakimdir ama bilmediği yerden çıkması öğrencinin ne ögrendiğini belirlemez...

SÖA4: Öğretmen bazen duygusal davranıp not kırabilip yükseltebiliyor ya da bazı sinavlarda şans faktörünün yüksek olması, ögrretmenin sinav sitili, öğrenen ögrencinin yüksek alması, kısa cevaplı sorularda kopya çekme oranının olması nedeniyle öğrencinin aldı̆̆ puanın ne öğrendiğini ortaya çıkarmayacă̆ını düşünüyorum. 
OÖÖA7: Bizim alanda ögrenciyi gözlem yaptı̆̆ımız için az çok aldĭ̆ı puan azda olsa yansitır. Çocuğun güçlü ve güçsüz yanların önceden belirlemek ve Çocuğun genellikle ne yaptı̆̆ ile ne yapabildiğini ayırabilme Gelecekteki gelişmeyi önceden tahmin edebilme gibi davranışları daha çok gözlediğimiz için aldı̆̆ı puan bence davranışı ögrenip öğrenmediğini gösterir. Okul öncesinde özelikle davranışın tekrarlanmasıyla öğrenildiği anlaşır.

Mülakata katılan öğretmen adaylarının değerlendirme okuryazarlığına ilişkin öz-yeterlikleriyle ilgili bazı sorular da yöneltilmiştir. Fen bilgisi, sınıf ve okul öncesi öğretmen adaylarıyla yapılan mülakatlar sonucunda alınan görüşlerden bazı örnekler aşağıda sunulmuştur.

Tablo 9. Öğretmen Adaylarının derecelendirme-ölçme araçlarını (rubrik) seçme, yöntemlerini geliştirme konusunda kendini yeterli hissetmeye yönelik görüşleri

\begin{tabular}{lccc}
\hline & Branşlar & F & \% \\
\hline Uygun derecelendirme ölçme araçlarını (rubrik) seçme, & FBÖA & 5 & 33 \\
\cline { 2 - 4 } $\begin{array}{l}\text { yöntemlerini geliştirme, tasarlama konusunda kendini yeterli } \\
\text { hissetme }\end{array}$ & SÖA & 5 & 33 \\
\cline { 2 - 4 } & OÖÖA & 2 & 13 \\
\hline
\end{tabular}

Mülakata katılan öğretmen adaylarından $10(\% 66,6)$ fen bilgisi, $10(\% 66,6)$ sınıf ve 13( \%86,6) okul öncesi öğretmen adayı, uygun ölçme-değerlendirme yöntem ve tekniklerini belirleme, geliştirme ve öğrencilere ilişkin elde ettikleri verileri analiz edip yorumlama ile ilgili teorik bilgilerini uygulama noktasında kendilerini daha az yeterli hissettiklerini söylemişlerdir. Ayrıca, 8 (\%53,3)fen bilgisi, 8 $(\% 53,3)$ sınıf ve $5(\% 33,3)$ okul öncesi öğretmen adayı da, üniversitede değerlendirme bilgisine ilişkin aldıkları derslerle mesleğe atıldıklarında başarılı bir şekilde öğrencilerini değerlendirecekleri bakış açısına sahip oldukları görülmüştür. Bunun nedeni olarak da, sadece geleneksel değerlendirme araçlarını (yazılı, sözlü, test, kısa cevaplı testler, boşluk doldurma, doğru-yanlış vb.) kullanacaklarını ve bu ölçme araçlarını da kolayca uygulayabileceklerini vurgulamışlardır. Öğretmen adaylarıyla yapılan bazı mülakat örnekleri aşağıda sunulmuştur:

Araştırmacı: Öğrencileri değerlendirirken kullanılacak uygun derecelendirme ölçme araçlarını (rubrik) seçme de yeterli olduğunuza inanıyor musunuz?

FBÖA5: Yeterli olduğumu düşünmüyorum özellik projelerde puanlamayı tarafsız bir şekilde kullanmada kendimi yetersiz görüyorum. Süreç değerlendirmesi yaparken öğrencileri nasıl değerlendireceğim noktasında sıkıntı yaşıyorum. Amacına uygun ölçme değerlendirme araçlarını seçemiyorum. 
SÖA9: Üniversite son sınıfim ve değerlendirme noktasında korkuyorum... Açıkçası ögretim süreci içerisinde yeni yöntem tekniklerle dersi işlerken değerlendirmede geleneksel değerlendirme türlerini kullanacağımı düşünüyorum. Alternatif değerlendirme teknikleri gelişstirme ya da tasarlama noktasında pek fazla bilgi sahibi değilim yani üniversite de teorik olarak aldiğımız çoğu dersleri vize ve finale girip unutuyorduk hangi teknik ne için kullanılır bilmiyorum...

FBÖA8: Geleneksel ölçme değerlendirme yöntemlerinden çoklu test, boşluk doldurma, yazılı ve sözlü gibi teknikleri kullanmada kendimi yeterli hissediyorum bu ölçekleri kullanırken ögrencilerin ne öğrendiklerini, eksik bilgileri tamamlama yanllş bilgilerini düzeltme yönünde dönüt düzeltme verebilirim.

Araştırmacı: Uygun ölçme ve değerlendirme yöntemlerini geliştirme, tasarlama konusunda kendinizi ne kadar yeterli hissediyorsunuz?

FBÖA11: Üniversiteden ölçme değerlendirme dersini gördüğümden beri değerlendirme noktasında korkuyorum açıkçası ögretim süreci içerisinde yeni yöntem tekniklerle dersi işlerken değerlendirmede geleneksel değerlendirme ölçme araçlarını tasarlayabilirim.

SÖA2: Gelişim dosyasına yönelik uygun dereceli puanlama anahtarı hazırlamak için bir ölçme ve değerlendirme uzmanina ihtiyaç duyuyorum ...

Araştırmacı: İçeriğe ve eğitim durumlarına uygun, farklı değerlendirme teknikleri geliştirebilir misiniz?

FBÖA7: Ölçme değerlendirme dersi en zorlandiğım konu geleneksel değerlendirme ölçme araçlarını kendim oluştururum ama alternatif değerlendirme tekniklerini oluşturmada kendimi yetersiz hissediyorum.

SÖA5: Öğrencilere, öğrencilerin üst düzey düşünme becerilerini geliştirici performans görevleri verebiliyorum... ve bu performansa bağlı davranışlarını ölçecek değerlendirme teknikleri geliştirebilirim.

OÖÖA8: Kendimi yeterli hissetmiyorum. Genellikle MEB'in ön gördüğü gözlem ölçeklerini kullaniyoruz. Davranışları ölçecek bazı ölçekler hazırllyoruz ama bu rastgele bir ölçek oluyor yani bir uzman görüşü ya da geçerlik ve güvenirlik klsmina bakmadan hazırlyyoruz... 
Tablo 10. Öğretmen Adaylarının Değerlendirme Okuryazarlığı ve Değerlendirme Okuryazarlığına İlişkin ÖzYeterlikleri Arasındaki İlişkiler

\begin{tabular}{|c|c|c|c|c|c|c|}
\hline & $\begin{array}{c}\text { FBÖA } \\
\text { Değerlendirme } \\
\text { Okuryazarlığı }\end{array}$ & $\begin{array}{l}\text { FBÖA Öz- } \\
\text { yeterlik }\end{array}$ & $\begin{array}{c}\text { SÖA } \\
\text { Değerlendirme } \\
\text { Okuryazarlığı }\end{array}$ & $\begin{array}{l}\text { SÖA Öz- } \\
\text { yeterlik }\end{array}$ & $\begin{array}{c}\text { OÖÖA } \\
\text { Değerlendirme } \\
\text { Okuryazarlığı }\end{array}$ & $\begin{array}{c}\text { OÖÖA } \\
\text { Öz- } \\
\text { yeterlik }\end{array}$ \\
\hline $\begin{array}{l}\text { FBÖA Değerlendirme } \\
\text { Okuryazarlığı }\end{array}$ & --- & & & & & \\
\hline FBÖA Öz-yeterlik & -.082 & --- & & & & \\
\hline $\begin{array}{l}\text { SÖA Değerlendirme } \\
\text { Okuryazarlığı }\end{array}$ & & & --- & & & \\
\hline SBÖA Öz-yeterlik & & & .074 & - & & \\
\hline $\begin{array}{l}\text { OÖÖA Değerlendirme } \\
\text { Okuryazarlığı }\end{array}$ & & & & & --- & \\
\hline OÖÖA Öz-yeterlik & & & & & -.200 & --- \\
\hline
\end{tabular}

Araştırmaya katılan öğretmen adaylarının değerlendirme okuryazarlı̆̆ ve değerlendirme okuryazarlığına ilişkin öz-yeterlik algıları arasındaki ilişkiler Tablo 10'da sunulmuştur. Fen bilgisi, sınıf ve okul öncesi öğretmen adaylarının sahip oldukları değerlendirme okuryazarlık düzeyleri ile değerlendirme okuryazarlığına ilişkin öz-yeterlikleri arasında istatistikî olarak anlamlı bir ilişkinin olmadığ1 bulunmuştur ( $\mathrm{r}=-0.082, \mathrm{p}=0.638 ; \mathrm{r}=0.074, \mathrm{p}=0.674 ; \mathrm{r}=-0.200, \mathrm{p}=0.249)$. Buna göre değerlendirme okuryazarlığı öğretmen adaylarının değerlendirme okuryazarlığına ilişkin öz-yeterlik algılarını etkilememektedir.

\section{SONUÇ VE TARTIŞMA}

\section{Öğretmen Adaylarının Değerlendirme Okuryazarlığına İlişkin Sonuçlar}

$\mathrm{Bu}$ çalışmada, farklı branşlardaki öğretmen adaylarının ölçme-değerlendirme okuryazarlık düzeyleri, Ölçme-değerlendirme Okuryazarlık Envanteri uygulanarak belirlenmeye çalışılmıştır. Çalışmaya katılan öğretmen adayları, 30 envanter maddesinin ortalama olarak 10 tanesine (\%30) doğru cevap verilmiştir. Mertler ve arkadaşları çalışmalarında aynı envanterin 35 maddeden ortalama olarak 21 tanesine ( \%60) doğru cevap verilmiştir. Mertler (2003) te yaptığı çalışmada 35 sorudan 19'unu (\%54) cevaplamıştır. Davidheiser (2013)'te yaptığı tez çalışmasında ise, Mertler ve Campbell (2005) tarafından geliştirilen “Ölçme ve Değerlendirme Ölçeği (Assessment Literacy Inventory (ALI))"ni Amerika'da merkez bölge sınırlarında çalışan lise öğretmenlerine internet üzerinden uygulamıştır. Çalışmanın sonucunda, öğretmenlerin 35 sorudan 24 "enü doğru cevaplayabildikleri belirlenmiştir. Fen bilgisi, sınıf ve okul öncesi öğretmen adaylarının değerlendirme okuryazarlığına ilişkin elde edilen nicel bulgular incelendiğinde, ölçme ve değerlendirme konusunda öğretmen adaylarının yeterli düzeyde 
bilgiye sahip olmadıkları tespit edilmiştir( $\mathrm{x}=10)$. Araştırma sonuçlarına bakıldığında; fen bilgisi ile sınıf öğretmen adaylarının ortalamaları arasında önemli bir fark olmamasına rağmen sınıf öğretmen adaylarının değerlendirme okuryazarlıklarının diğer branşlara göre daha iyi düzeyde olduğu, okul öncesi öğretmen adaylarının da düşük düzeyde olduğu tespit edilmiştir. Bu sonuçlar, literatürdeki bazı çalışmaların sonuçlarıyla da uyumludur (Karaman, 2014; Kilmen, Kösterelioğlu \& Kösterelioğlu, 2007; King, 2010 vb.). Yapılan çalışmalarda farklı branşlardaki öğretmen adaylarının ortalamalarının birbirinden farklı çıkmasının olası bir durum olduğu belirtilmektedir. Çünkü öğretmen adaylarının almış oldukları eğitim-öğretim süreçleri (uygulanan öğretim programı, kazanılan deneyimler, öğretim üyelerinin öğretim yöntemleri gibi) birbirinden farklıdır. Eğitim fakültelerinde yürütülen öğretmen yetiştirme programlarının genel olarak konu başlıkları birbirine benzer olsa da ders içeriklerinin farklı olması, dersi işleyen öğretim elemanlarının değerlendirme okuryazarlığına ilişkin bilgilerinin yeterli olmaması bulguların bu yönde olmasına sebep gösterilebilir. Ayrıca ders sürecinde kullandıkları ögretim strateji, yöntem ve tekniklerinin farklı olması, okul deneyimi derslerinde teoriyi uygulama firsatının verilmemesi, teori ve uygulamaların paralel bir şekilde sürdürülmemesi vb. sebeplerden ötürü bu tip sonuçların ortaya çıkması olağandır. Örneğin, fen bilgisi ve sınıf öğretmen adayları mülakatlarda lisans öğrenimlerinde öğretim strateji, yöntem ve teknikleri ile ölçme ve değerlendirme yaklaşım ve araçlarıyla ilgili aldıkları teorik ve uygulamalı eğitimlerle ilgili birçok somut örnekler vererek kısmen de olsa bilimsel olarak yeterli açıklamalarda bulunmuşlardır.

Ölçme-Değerlendirme Okuryazarlık Envanteri’nden elde edilen verilere uygulanan MANOVA analizine göre, fen bilgisi, sınıf ve okul öncesi ögretmen adaylarının değerlendirme okuryazarlıkları arasında anlamlı bir farklılığın olduğu belirlenmiştir. Ayrıca, fen bilgisi öğretmen adayları ile okul öncesi öğretmen adayları arasında istatistiksel olarak anlamlı bir farklılı̆̆ın olmadığı; sınıf öğretmen adaylarının fen bilgisi ve okul öncesi öğretmen adayları ile istatistiksel olarak anlamlı bir farklılığın olduğu da görülmüştür.

Mülakatlardan elde edilen verilere göre, öğretmen adaylarının değerlendirme okuryazarlığına ilişkin yeterli düzeyde bilgiye sahip olmadıkları görülmüştür. Birçok öğretmen adayının değerlendirme noktasında kendilerini yeterli görmedikleri ve daha çok geleneksel değerlendirme ölçme araçlarını kullandıklarını/kullanacaklarını belirtmişlerdir. Birgin (2007)'de sınıf öğretmenleriyle yaptığg nitel bir araştırmada sınıf öğretmen adaylarının değerlendirme alanında okuryazarlık düzeylerini incelemiştir. Sınıf öğretmenliği 80 öğretmen adayına açık uçlu sorulardan oluşan bir mülakat tekniğiyle değerlendirme bilgisini ve becerilerini ölçmeye çalışmıştır. Elde edilen verilerin analizin sonucunda, öğretmen adaylarının daha çok geleneksek değerlendirme yaklaşımlarını kullanmak istediklerini belirtmiştir. Öğretmen adayları özellikle değerlendirme metotlarını seçebilme ve geliştirebilme noktasında sıkıntı yaşadıklarını belirtirken, puanlama ve yorumlama kısmında herhangi bir sıkıntı yaşamadıklarından bahsetmişlerdir (Tablo 7). Çünkü puanlama ve yorumlamada, geleneksel değerlendirme yaklaşımı doğrultusunda ölçme araçlarını kullandıkları için 
puanlamanın daha kolay olduğunu ve alınan puan aralığının neye denk geldiğini yorumlamada kolaylık sağladığını söylemişlerdir. Bazı öğretmen adayları da, öğretmen kılavuz kitabının sonundaki hazır ölçme araçları şablonlarını kullandıklarını ve kendilerine göre puanlama yaptıklarını söylemişlerdir. Ayrıca öğretmen adaylarının çoğu alternatif ve otantik değerlendirmede bilgi ve beceri veya performans puanlama sürecinin karmaşık olduğunu ve objektif bir değerlendirme yapmanın zor olacağını belirterek, bu değerlendirme yaklaşımlarını kullanmayacaklarını ifade etmişlerdir. Literatürde de, hizmet içi ve hizmet öncesi öğretmenler alternatif ve otantik değerlendirme sürecinin faydalı olduğunu düşünseler de objektif puanlama yapma, ölçme-değerlendirme araçlarını tasarlama ve etkili bir şekilde uygulama noktasında yeterli zamanları olmayacağı gibi birçok nedenden dolayı uygulamayacaklarını belirttikleri bazı çalışmalar mevcuttur (Graham, 2005; Suzuk \& Ogan-Bekiroglu, 2012 vb). Bunun genel nedenleri olarak, öğretmen adaylarının üniversiteye gelinceye kadar ve üniversitede geleneksel değerlendirme yaklaşımlarıyla değerlendirilmeleri ve geleneksel öğretmen eğitiminde teorik olarak öğrendikleri değerlendirme yaklaşımlarını mesleğe başladıkları zaman kolayca, sorunsuz bir şekilde uygulayacaklarını düşünmeleridir (Fernandez ve Robinson, 2007). Bu bağlamda, eğitim fakültelerinde verilen ölçme ve değerlendirmeyle ilgili teorik ve uygulamalı dersleri bütünleştirecek ve 21. yüzyılda yetiştirilen öğretmen adaylarının değerlendirme okuryazarlıklarını geliştirebilecek nitelikte bu sürecin yürütülmesi gerekmektedir (DeLuca ve Klinger, 2010).

Bunlara ek olarak, mülakatlara katılan fen bilgisi öğretmen adaylarının sınıf ve okul öncesi öğretmen adaylarına göre değerlendirme okuryazarlığına yönelik bilgilerinin daha yeterli olduğu görülmüştür. Örneğin, fen bilgisi öğretmen adayları özellikle değerlendirme bilgisi, değerlendirme yaklaşımları ve yöntemleri uygulayabilme, sonuçları yorumlayabilme ve sonuçları öğrenci, okul ve aileler ile paylaşabilme vb. değerlendirme okuryazarlığına yönelik bilgilere kısmen yeterli düzeyde sahip olduğu tespit edilmiştir. Fakat fen bilgisi öğretmen adaylarının çoğunun değerlendirme sürecinde kullanacakları araçları tasarlayabilme, geliştirebilme ve not verme işlemlerini geliştirebilme, öğrencinin aldığı puanı yorumlayabilme, öğrenciyi değerlendirme sürecine katabilme gibi yeterliklerinin oldukça zayıf olduğu belirlenmiştir. Ayrıca, bazı fen bilgisi öğretmen adayları alternatif değerlendirme tekniklerini süreç ve sonuç değerlendirmelerinde kullanacaklarını belirterek, öğrencilerin ön bilgilerini açığa çıkarma, öğrenciyi süreç içerisinde nasıl gelişim gösterdiğini belirlemek için Tahmin et-AçıklaGözle-Açıkla (TAGA), Kavram Haritaları, Kavram Karikatürleri gibi bazı ölçme araçlarını Okul Deneyimi dersinde kullandıklarını belirtmişlerdir (Tablo 7). Sınıf öğretmen adayları ise, daha çok geleneksel değerlendirme tekniklerini kullanacaklarını belirtmişlerdir. Sınıfların kalabalık olmasından yakınan öğretmen adayları okul deneyimi dersi kapsamında gittikleri okullarda, alternatif değerlendirme yaklaşımlarının kullanılmasının zor olduğu ve süreç değerlendirmesinde genellikle soru-cevap tekniğini kullandıklarını/kullanacaklarını belirtmişlerdir. Mülakatlara katılan okul öncesi öğretmen adaylarının da, değerlendirme okuryazarlığına yönelik sahip olduğu bilgilerinin diğer öğretmen adaylarına göre daha zayıf olduğu görülmüştür. Bu öğretmen adayları, değerlendirme araçlarını kendileri oluşturmak yerine MEB'in belirtmiş olduğu gözlem formu, anektod, rubrik gibi hazır şablonları ve öğrencilerin 
davranışlarının gözlenip gözlenmediğini belirttikleri simgeler, semboller kullandıklarını vurgulamışlardır.

Öğretmen Adaylarının Değerlendirme Okuryazarlığına İlişkin Öz-Yeterlikleriyle İlgili Sonuçlar

Fen bilgisi, sınıf ve okul öncesi öğretmen adaylarının değerlendirme okuryazarlığına ilişkin özyeterlik algılarıyla ilgili elde edilen bulgular incelendiğinde, değerlendirme okuryazarlığına ilişkin özyeterlik algılarının yeterli düzeyde olmadığı belirlenmiştir. Araştırmaya katılan fen bilgisi öğretmen adaylarıyla ile sınıf öğretmen adaylarının ortalamaları arasında önemli bir fark olmamasına rağmen, sınıf öğretmen adaylarının değerlendirme okuryazarlığına ilişkin öz-yeterlik algılarının diğer branşlara göre daha iyi düzeyde olduğu görülmüştür. Okul öncesi öğretmen adaylarının da fen ve sınıf öğretmen adaylarına göre düşük düzeyde olduğu tespit edilmiştir(Tablo 5). Bu sonuçların en önemli sebepleri, öğretmen adaylarının üniversitelerde değerlendirme okuryazarlıklarını geliştirmeye yönelik birebir dersleri almamaları ve ara-yıl sonu sınavlarının belirli bir süre içerisinde genellikle kağıt-kalemle yapılan geleneksel açık-uçlu sorular, çoktan seçmeli, kısa cevaplı ve boşluk doldurmalı testlerden yararlanarak yapılması vb. olduğu söylenebilir. Çünkü öğretmen adaylarının değerlendirme (alternatif ve otantik değerlendirme) okuryazarlı̆̆ıyla ilgili yeterli bilgi ve beceri sahibi olmamaları ve geleneksel olarak değerlendirilmeleri değerlendirme okuryazarlığına ilişkin öz-yeterlik algılarının önündeki en önemli engeller olarak görülebilir. Öğretmen ve öğretmen adaylarının inançlarının, çoğunlukla üniversite eğitimleri süresince karşılaştıkları sorunlar ve yaşadıkları deneyimlere göre şekillenerek oluştuğu vurgulanmaktadır (Pajares, 1992; aktaran Karaman, 2014). Bu bağlamda, öğretmen adaylarının değerlendirme okuryazarlıklarına yönelik öz-yeterlik algılarının gelişimi bölümündeki eğitim süreçleri boyunca aldıkları teorik derslerdeki kazanımları ve uygulamalarıyla (staj) doğrudan ilişkili olduğu söylenebilir. $\mathrm{Bu}$ araştırmanın sonuçları, literatürdeki bazı çalışmaların sonuçlarıyla da uyumludur (Akdağ, 2011; Volante \& Fazio, 2007 gibi).

Eğitimde Ölçme ve Değerlendirmeye Yönelik Öz-yeterlik Algı Ölçeği’nden elde edilen verilere uygulanan MANOVA analizine göre, fen bilgisi, sınıf ve okul öncesi öğretmen adaylarının değerlendirme okuryazarlığına ilişkin öz-yeterlik algıları arasında anlamlı bir farklılığın olduğu görülmüştür. Ayrıca, fen bilgisi öğretmen adayları ile okul öncesi öğretmen adayları arasında istatistiksel olarak anlamlı bir farklılığın olmadığı; sınıf öğretmen adaylarının fen bilgisi ve okul öncesi öğretmen adayları ile istatistiksel olarak anlamlı bir farklılığın olduğu da görülmüştür.

Araştırmada mülakata katılan fen bilgisi, sınıf ve okul öncesi öğretmen adaylarından elde edilen verilere göre de, öğretmen adaylarının değerlendirme okuryazarlığına ilişkin öz-yeterliklerinin yeterli düzeyde olmadığı tespit edilmiştir. Öğretmen adaylarının birçoğunun, genel olarak, üniversitede değerlendirme bilgisine ilişkin aldıkları derslerle mesleğe atıldıklarında başarılı bir şekilde öğrencilerini değerlendirecekleri bakış açısına sahip oldukları görülmüştür. Bunun nedeni olarak da, geleneksel değerlendirme araçlarını (yazıll, sözlü, test, kısa cevaplı testler, boşluk doldurma, doğru-yanlış vb.) kolayca uygulayabilecekleri olduğunu belirtmişlerdir. Ayrıca, mülakata katılan öğretmen adaylarının 
vermiş oldukları cevaplara göre, değerlendirme okuryazarlığına ilişkin teorik bilgilerini uygulamada kendilerini daha az yeterli hissettikleri tespit edilmiştir. Bandura (1995) ve Hill, Smith \& Mann (1987), bireylerin davranışları ile deneyimleri arasında deneyimleriyle de öz-yeterlik algılarının gelişmesi arasında bir ilişki olduğunu belirtmişlerdir. Bu nedenle, öğretmen adaylarının kazandıkları teorik bilgilerini sürekli ve etkili bir şekilde uygulamaları konusunda öğretmen eğitimi programlarının geliştirilmesi gerektiği düşünülmektedir.

Öğretmen Adaylarının Değerlendirme Okuryazarlı̆̆ı ve Değerlendirme Okuryazarlığına İlişkin Öz-Yeterlikleri Arasındaki İlişkilerle İlgili Sonuçlar

Fen bilgisi, sınıf ve okul öncesi öğretmen adaylarının değerlendirme okuryazarlığı ve değerlendirme okuryazarlığına ilişkin öz-yeterlikleri arasında istatistiksel olarak anlamlı bir ilişkinin olmadığı tespit edilmiştir Buna göre değerlendirme okuryazarlığ öğretmen adaylarının değerlendirme okuryazarlığına ilişkin öz-yeterlik algılarını etkilememektedir. Bu durum, öğretmen adaylarıyla yapılan mülakatlarda, alternatif ve otantik değerlendirmeler hakkında yeterli bilgiye sahip olmadıkları için iyi bildikleri geleneksel değerlendirme araçlarını yeterli düzeyde kullanacakları şeklinde açıklamışlardır. Yani üç farklı branştaki öğretmen adaylarının değerlendirme okuryazarlığına ilişkin hem teorik hem de uygulama açısından iyi düzeyde bilgileri olmamasına rağmen, sadece geleneksel değerlendirme ve araçgereçlerini düşünerek kendilerini bu konuda yeterli hissettikleri düşünülmektedir. Ayrıca mülakata katılan bazı öğretmen adayları, değerlendirme okuryazarlığına ilişkin teorik bilgilerini uygulamada kendilerini daha az yeterli hissettiklerini de belirtmişlerdir. Literatürde yapılan çalışmalarda da bu durum belirtilmektedir (Alkharusi, Aldhafri, Alnabhani \& Alkalbani, 2012 vb).

\section{Öneriler}

Son yıllarda, değerlendirme kavramı önemli araştırma konuları arasında yer almakta ve bu konuda birçok araştırma yapılmaktadır. Eğitim fakültelerinde birçok araştırmacı tarafindan bu konu üzerine çalışmalar yürütülmektedir. $\mathrm{Bu}$ araştırmaların genel sonucu olarak, değerlendirme okuryazarlığı seviyesinde öğretmen adaylarının yetiştirilmediği söylenebilir (Gelbal \& Kelecioğlu, 2007). Ülkemizde yapılan çalışmalarda da, öğretmen yetiştirme sistemlerinin "Değerlendirme Okuryazarlığı" gibi ana kavramlar üzerine inşa edilmediği belirtilmektedir. Buna göre, programların bu ana kavramlar dâhilinde geliştirilmesi, 21. yüzyıl becerileri kapsamında güncellenmesi ve bu programlar dahilin de öğretmen adaylarının değerlendirme okuryazarlıklarının geliştirilmesi için ölçme ve değerlendirme yeterlik alanları göz önünde bulundurularak etkinlikler düzenlenmeli ve yürütülmelidir (Beziat \& Coleman, 2015). Ayrıca, öğretmen adaylarının lisans eğitimleri süresince geleneksel değerlendirmeler (vize-final sınavi) yerine hem sürecin hem de sonucun değerlendirildiği proje, portfolyo, poster, performans değerlendirme, öz ve akran değerlendirme vb. üzerinden değerlendirilmesi veya bu değerlendirme süreçlerini birebir uygulayabilme imkânı tanınması gerektiği düşünülmektedir.

Literatürde, değerlendirme okuryazarlığının gelişimiyle birlikte öğretmen adaylarının ölçme ve değerlendirmeye ilişkin düşüncelere, tutumlara ve inançlara da sahip olmasının önemli olduğu 
vurgulanmaktadır. $\mathrm{Bu}$ nedenle, öğretim programlarıyla hem öğretmen adaylarının değerlendirme okuryazarlıklarının hem de değerlendirmeye ilişkin öz-yeterliklerinin geliştirilmesi gerekmektedir. Bu da ancak, üniversitelerin özellikle eğitim fakültelerindeki öğretim elemanlarının ölçme-değerlendirme yeterlik alanlarına sahip olması, eğitim süreçlerini bu çerçevede planlaması ve yürütmesiyle gerçekleşecektir. Bunlara ek olarak, ülkemizde öğretmen yetiştirme programları incelendiğinde, öğretmen adaylarına bir yıl içerisinde sınırlı ders saatinde ölçme ve değerlendirme dersi verilmektedir. Alınan bu dersler, öğretmen adaylarına değerlendirme okuryazarlığına ilişkin yeterlik alanları kapsamında teorik ve uygulamalı dersler şekilde verilmelidir. Böylece, bu derslerle birlikte öğretmen adayları iyi bir eğitim alarak meslek hayatlarına başladıkları zaman kendilerini daha yeterli hissedeceklerdir.

\section{KAYNAKLAR}

Akdağ, G. (2011). Fen ve Teknoloji Öğretmenlerinin Ölçme ve Değerlendirmeye İlişsin Yeterlilik Algıları ve Görüşleri (Adıyaman ili örneği) (Yüksek Lisans Tezi), Adıyaman Üniversitesi, Fen Bilimleri Enstitüsü, Adıyaman.

Alkharusi, H., Aldhafri, S., Alnabhani, H. \& Alkalbani, M. (2012). Educational assessment attitudes, competence, knowledge, and practices: An exploratory study of Muscat teachers in the Sultanate of Oman. Journal of Education and Learning, 1 (2), 217-232.

Bandura, A. (1995). Exercise of Personel and Collective Efficacy in Changing Socities. In A. Bandura (Ed.). Self-Efficacy in Changing Socities. New York: Cambridge University Press (pp. 1-45).

Beziat, T. L. R. \& Coleman, B. K. (2015). Classroom Assessment Literacy: Evaluating Pre-service Teachers. The Researcher, 27 (1), 25-30.

Birgin, O. (2007). Sınıf öğretmeni adaylarının ölçme-değerlendirme konusundaki okuryazarlık düzeylerinin incelenmesi. 5-7 Eylül 2007, XVI. Ulusal Eğitim Bilimleri Kongresi, Gaziosmanpaşa Üniversitesi, Tokat

Bonner, S. M. \& Chen, P. P. (2009). Teacher candidates' perceptions about grading and constructivist teaching. Educational Assessment, 14, 57-77.

Bütüner, S. Ö., Yiğit, N. \& Çimer, S. O. (2010). Ölçme Değerlendirme Okuryazarlı̆ğ Envanterinin Türkçeye Uyarlanması. E-Journal of New World Sciences Academy, 5 (3), 792-809.

Davidheiser, A. S. (2013). Identifying Areas for High School Teacher Development: A Study of Assessment Literacy in the Central Bucks School District. Doctoral Thesis, Drexel University, School of Education, Philadelphia.

DeLuca, C. \& Klinger, D. (2010). Assessment Literacy Development: Identifying Gaps in Teacher Candidates' Learning. Assessment in Education: Principles, Policy \& Assessment in Education, 17 (4), 419-438. 
Ebenezer, J., Chacko, S., Kaya, O. N., Koya, S. K. \& Ebenezer, D. L. (2010). The Effects of Common Knowledge Construction Model Sequence of Lessons on Science Achievement and Relational Conceptual Change. Journal of Research in Science Teaching, 47, 25-46.

Fernandez, M. L. \& Robinson, M. (2006). Prospective Teachers' Perspectives on Microteaching Lesson Study. Education, 127 (2), 203-215.

Fulcher, G. (2012). Assessment Literacy for the Language Classroom. Language Assessment Quarterly, 9 (2), 113-132.

Gelbal, S. \& Kelecioğlu, H. (2007). Öğretmenlerin Ölçme ve Değerlendirme Yöntemleri Hakkındaki Yeterlik Algıları ve Karşılaştıkları Sorunlar. Hacettepe Üniversitesi Eğitim Fakültesi Dergisi, $33,135-145$.

Graham, P. (2005). Classroom-Based Assessment: Changing Knowledge and Practice Through Preservice Teacher Education. Teaching and Teacher Education, 21 (6), 607-621.

Gül, E. (2011). İlköğretim Öğretmen Adaylarının Ölçme-Değerlendirme Okuryazarlı̆̆ı ve ÖlçmeDeğerlendirmeye İlişkin Tutumlarının Belirlenmesi (Yüksek Lisans Tezi), Fırat Üniversitesi, Fen Bilimleri Enstitüsü, Elazı̆̆.

Hill, T., Smith, N. D. \& Mann, M. F. (1987). Role of Efficacy Expectations in Predicting the Decision to Use Advanced Technologies: The Case of Computers. Journal of Applied Psychology, 72 (2), 307-313

İşman, A. \& Eskicumal1, A. (2003). Eğitimde Planlama ve Değerlendirme. İstanbul: Değişim Yayınları.

Karaman, P. (2014). Öğretmen Adaylarının Ölçme-Değerlendirme Okuryazarlıklarının Belirlenmesi ve Mikro-Öğretim Yoluyla Geliştirilmesi (Doktora Tezi), On Sekiz Mart Üniversitesi, Eğitim Bilimleri Enstitüsü, Çanakkale.

Kılınç, M. (2011). Öğretmen Adaylarının Eğitimde Ölçme ve Değerlendirmeye Yönelik Özyeterlik Alg1 Ölçeği. Ahi Evran Üniversitesi Kırşehir Eğitim Fakültesi Dergisi (KEFAD), 12, (4), 8193.

Kilmen, S., Akın Kösterelioğlu, M. \& Kösterelioğlu, İ. (2007). Öğretmen Adaylarının Ölçme Değerlendirme Araç ve Yaklaşımlarına İlişkin Yeterlik Algıları. Abant İzzet Baysal Üniversitesi Eğitim Fakültesi Dergisi, 7 (1), 117-127.

King, J. D. (2010). Criterion-Referenced Assessment Literacy of Educators. Unpublished Doctoral Thesis. The University of Southern Mississippi. http://aquila.usm.edu/cgi/viewcontent.cgi?article=2010\&context=dissertations

Mertler, C. A. \& Campbell, C. S. (2005, April). Measuring Teachers' Knowledge and Application of Classroom Assessment Concepts: Development of the Assessment Literacy Inventory. Paper presented at the annual meeting of the American Educational Research Association, Montreal, QC, Canada. http://files.eric.ed.gov/fulltext/ED490355.pdf 
Milli Eğitim Bakanlığı (2006). İlköğretim Fen ve Teknoloji Dersi (6, 7 ve 8. Sinıflar) Öğretim Program1, Ankara.

Milli Eğitim Bakanlığg (2013). İlköğretim Kurumları (İlkokullar ve Ortaokullar) Fen Bilimleri Dersi (3, 4, 5, 6, 7 ve 8. Sinıflar) Öğretim Programı, Ankara.

Pajares, M. F. (1992). Teachers' Beliefs and Educational Research: Cleaning up a Messy Construct. Review of Educational Research,62 (3), 307-332.

Plake, B.S., Impara, J.C., \& Fager, J.J. (1993). Assessment competencies of teachers: A national survey. Educational Measurement: Issues and Practice, 12 (4), 10-12, 39.

Stiggins, R. (2008). Assessment Manifesto: A Call for the Development of Balanced Assessment Systems. Portland, OR: ETS Assessment Training Institute. http://www.nyscoss.org/img/uploads/file/Assessment Manifesto Article - Rick Stiggins.pdf

Suzuk, E. \& Ogan-Bekiroğlu, F. (2012). Pre-Service Physics Teachers' Intentions Toward Classroom Assessment. Procedia - Social and Behavioral Sciences, 69 (107), 854-863.

Tao, N. (2014). Development and Validation of Classroom Assessment Literacy Scales: English as a Foreign Language (EFL) Instructors in a Cambodian Higher Education Setting. Doctoral dissertation, Victoria University, College of Education, Melbourne, Australia. http://vuir.vu.edu.au/25850/1/Nary\%20Tao.pdf

Tschannen-Moran, M. (2001). Collaboration and the need for trust. Journal of Educational Administration, 39, 308-331.

Volante, L. \& Fazio, X. (2007). Exploring Teacher Candidates' Assessment Literacy: Implications for Teacher Education Reform and Professional Development. Canadian Journal Of Education, 30 (3), 749-770.

Yılmaz, M., Köseoğlu, P., Gerçek, C., ve Soran, H. (2004). Yabancı Dilde Hazırlanan Bir Öğretmen Özyeterlik Ölçeğinin Türkçeye Uyarlanması. Hacettepe Üniversitesi Eğitim Fakültesi Dergisi, 27, 260-267.

\section{Extended Abstract}

In the present study, the assessment literacy and self-efficacy about assessment literacy of pre-service science, elementary and preschool teachers were investigated using the survey method. Furthermore, the relationships between pre-service teachers' assessment literacy and self-efficacy about assessment literacy were examined in this study. A total of 105 pre-service teachers who attended Frrat University, Faculty of Education, Department of Mathematics and Science Education and Department of Primary Education, Science, Elementary and PreSchool Teacher Training programs in the 2015-2016 academic year, 35 pre-service teachers from each program participated in this study, which was conducted with a combination of qualitative and quantitative research approaches. An inventory, questionnaire, and individual semi-structured interviews were used to determine the pre-service teachers' assessment literacy and assessment literacy about self-efficacy in the study. 
“The Assessment Literacy Inventory" developed by Mertler \& Campell (2005) was used to define the assessment literacy of pre-service science, elementary, and preschool teachers. This inventory was adapted to Turkish by Bütüner et al. The 5-point Likert-type The Scale for Measurement and Evaluation Self-Efficacy in Education was used to determine the pre-service teachers' self-efficacy about assessment literacy. Inventory and questionnaire were applied simultaneously to 35 pre-service science, elementary and preschool teachers. Individual semistructured interviews that lasted an average of 45 minutes were conducted with a random sample of 15 volunteer pre-service teachers. All interviews were recorded with a voice recorder. Multivariate Analysis of Variance (MANOVA) and Pearson Correlation Analysis were used to evaluate the data obtained from the result of this study in order to investigate the pre-service science, elementary and preschool teachers' assessment literacy and selfefficacy about assessment literacy. The data obtained from the interview that is a qualitative data collection tool were analyzed using content analysis method.

The statistical analyses of data revealed that there were statistically significance differences among the pre-service science, elementary and preschool teachers as regards to the levels of assessment literacy and selfefficacy about assessment literacy. When mean pre-service teacher scores were compared based on the independent variables, it was determined that pre-service elementary teachers' assessment literacy levels and their self-efficacy perceptions about assessment literacy were higher when compared to pre-service science and preschool teachers. Furthermore, it was determined that the pre-service science teachers who participated in the interviews conducted in this study had higher assessment literacy and self-efficacy about assessment literacy when compared to pre-service elementary and preschool teachers. It was also observed that the pre-service preschool teachers' assessment literacy and self-efficacy about assessment literacy were lower when compared to the other pre-service teachers. These findings are consistent with the results of some studies in the literature. In the studies, It is stated that it is a possible situation that the mean scores of the pre-service teacher in different branches differ from each other. This was due to the differences in the educational and instructional processes (such as the curriculum, experiences, faculty members' instructional methods) that the pre-service teachers are trained at university. In addition to these, it was determined that there was no statistically significant correlation between pre-service science, elementary, and preschool teachers' assessment literacy and self-efficacy about assessment literacy. In other words, it has been concluded that the self-efficacy about assessment literacy of a pre-service teacher was inadequate while the assessment literacy of the same pre-service teacher was adequate or a pre-service teacher' the assessment literacy was inadequate while the self-efficacy about assessment literacy of same preservice teacher was adequate. This was explained by the pre-service teachers in the interviews that they would use the traditional assessment tools that they are good enough as they do not have enough knowledge about alternative and authentic assessments. In other words, it has been concluded that although the pre-service teachers in three different branches did not have adequate theoretical and applied knowledge on assessment literacy, they had high self-efficacy perceptions about assessment literacy because they considered that they have enough knowledge about traditional assessment tools. It is emphasized in the literature that it is important that they have the considerations, attitudes, and beliefs on assessment for the development of pre-service teachers' assessment literacy. In this context, it is necessary to develop both the assessment literacy and self-efficacy about assessment literacy of pre-service teachers in teacher training programs. 